2016-07-30

\title{
Overcoming Barriers and Problem
}

\section{Solving}

\author{
Lynch, TJ
}

http://hdl.handle.net/10026.1/6379

10.1007/978-3-319-31667-3_10

Springer International Publishing

All content in PEARL is protected by copyright law. Author manuscripts are made available in accordance with publisher policies. Please cite only the published version using the details provided on the item record or document. In the absence of an open licence (e.g. Creative Commons), permissions for further reuse of content should be sought from the publisher or author. 


\title{
Overcoming Barriers and Problem Solving
}

\begin{abstract}
The purpose of this chapter is to investigate the difficulties within partnerships, the problems to be solved. The UN state that 'partnerships' are essential for implementation of the SDGs but also acknowledge that many barriers must be overcome. This is evidenced by the UN Economic and Social Council special event; '2015 Multi-Stakeholder partnerships: Making them work, for the Post 2015 Development Agenda'. There were many obstacles during the Health, Well-being and Physical Education (HW \& PE) project and insights are shared for the benefit of stakeholders in a similar context.
\end{abstract}

This chapter investigates the difficulties with partnerships, the trials and tribulations. The UN states that 'partnerships' are essential for implementation of the SDGs and continued efforts towards equality in health and wellbeing. However, they also acknowledge that many barriers must be overcome and problems solved as evidenced by the UN Economic and Social Council special event titled '2015 Multi-Stakeholder partnerships: Making them work, for the Post 2015 Development Agenda'. There were many obstacles during the Health, Well-being and Physical Education (HW \& PE) project, 'Best Start: A community collaborative approach to lifelong health and wellness'.

Partnerships often fail due to the complex and cumbersome problems that arise, what Leisinger refers to as 'wicked' problems. Wicked prob-

(C) The Editor(s) (if applicable) and The Author(s) 2016

T. Lynch, The Future of Health, Wellbeing and Physical Education, DOI 10.1007/978-3-319-31667-3_10 
lems are "not evil, but tricky, devious, messy and big, with interacting and evolving dynamics of social societal context" (Leisinger 2015). This is supported by research by Pattberg et al. (2012) who found that less than one quarter of partnerships output aligned directly with their stated goals.

Overcoming barriers and problem solving has strong connections to the 'how' of partnerships and is often dependent upon context. Context is the sub-heading for the last three stages of the International Civil Society Centre 'Nine building blocks for successful partnerships' (2014, p. 14), referenced throughout the storyline. The building blocks were identified for creating successful multi-stakeholder partnerships based on over 15 years of research from successful and failed partnerships (ICSC 2014).

\section{Context}

\section{Meta-governance}

Partnerships are an indication of an emerging property of global governance, namely, fragmentation, which is characterised by uncoordinated and non-hierarchical institutional arrangements, often leading to overlap and competition among initiatives within one and the same issue area. Without coordination, fragmentation could lead to inefficiencies, redundancies, and a seemingly large governance landscape, but with little real impact. (ICSC 2014 , p. 28).

The ideal of the community collaborations was to create a 'hybrid space', involving "non hierarchical interplay between academic, practitioner and community expertise" (Zeichner 2010, p. 89). The reality of meta-governance is often the reverse of this purpose, where conflict between stakeholders is experienced with counterproductive results.

Competition and overlap was present from the very beginnings of the project (January 2011). There was initial resistance by the leader to complete the Certificate IV in Training and Assessment as while it was clear that this was the requirement for anyone wishing to become a swimming and water safety presenter, it did seem somewhat inconsistent that previous teaching experience was not recognised as 'training and assessment'. A university lecturer with a number of education degreesall of a higher AQF Framework level-was then required to complete 
to overcome and problems to be solved, efforts and time invested were greatly valued by all stakeholders.

Responses from stakeholders suggested that they all valued the enhanced learning community collaboration generated. The children from the local primary schools were excited, parents attended lessons in support and comments from teachers, teaching assistants, parents, and the children expressed gratitude. We are reminded by Lawrence (2015) that different interests will always exist and they are not a barrier to success, rather "different interests create the intellectual tension that allows you to find better ways to solve problems".

\section{REFERENCES}

Australian Broadcasting Corporation. (2012, August 27). Why does school funding need to be reviewed? $A B C$ News. Retrieved from http://www.abc.net.au/ news/2012-08-27/whats-in-the-gonski-report/4219508

Austswim Australian Council for the Teaching of Swimming and Water Safety. (2009). Teaching swimming and water safety the Australian way (2nd ed.). Sydney, NSW: Mosby.

Balatti, J., \& Falk, I. (2000). Community capacity and vocational education and training. Hobart, TAS: Centre for Research and Learning in Regional Australia, University of Tasmania.

Centre for Research and Learning in Regional Australia. (2001). Building dynamic learning communities. Ten regional case studies. Launceston, TAS: Centre for Research and Learning in Regional Australia, University of Tasmania.

Clayton, B., Blom, K., Bateman, A., \& Carden, P. (2004). What works where you are? The implementation of training packages in rural Australia. Retrieved from http://files.eric.ed.gov/fulltext/ED495190.pdf

Datnow, A. (1998). The gender politics of educational change. London: Falmer Press.

Department of Education and Early Childhood Development. (2011, August). A tertiary education plan for Gippsland, Victoria (Discussion paper). Retrieved from http://www.education.vic.gov.au/Documents/about/programs/distanceed/tertedupgipps.pdf

Dinan-Thompson, M. (2001). Teachers facing health and physical education curriculum changes: A kaleidoscope of beliefs, values, emotions and interactions. ACHPER Healthy Lifestyles Journal, 48 (1), 9-13.

Dinan-Thompson, M. (2002). Curriculum construction and implementation: A study of Queensland health and physical education. Brisbane, QLD: University of Queensland Press. 
Ewing, R. (2010). Curriculum and assessment: A narrative approach. South Melbourne, VIC: Oxford University Press.

Fullan, M. (1982). The meaning of educational change. New York: Teachers College Press.

Garvis, S., \& Pendergast, D. (2014). Health and wellbeing in childhood. Port Melbourne, VIC: Cambridge University Press.

Gosper, S. (2012, June 9). Austswim accused of elbowing out rivals. The Australian.

Hargreaves, A. (1997). Rethinking educational change with heart and mind. Alexandria, VA: Association of Curriculum and Development.

International Civil Society Centre. (2014). Multi-stakeholder partnerships: Building blocksfor success. Retrieved from https://icscentre.org/downloads/14_10_02_ Multi-Stakeholder_Partnerships.pdf

Lawrence, G. (2015, February 27). Vice President and Chief Sustainability OfficerAECOM Technology Corporation, United Nations Economic and Social Council special event panelist-'2015 Multi-stakeholder partnerships: Making them work, for the Post-2015 Development Agenda'. Retrieved from http://webtv.un.org/watch/ multi-stakeholder-partnerships-making-them-work-for-the-post-2015development-agenda-economic-and-social-council/4084615948001

Leisinger, K. (2015, February 27). Founder and President, Global Values Alliance Foundation-World Vision, United Nations Economic and Social Council special event panelist-'2015 Multi-stakeholder partnerships: Making them work, for the Post-2015 Development Agenda'. Retrieved from http://webtv.un.org/watch/ multi-stakeholder-partnerships-making-them-work-for-the-post-2015development-agenda-economic-and-social-council/4084615948001

Lynch, T. (2012). Rips, currents and snags: Investigating the delivery of educational goals for young Australians in the region of Gippsland, Victoria. Australian and International Journal of Rural Education, 22(3), 1-18.

Owen, C., \& Bound, H. (1998). Industry learning priorities: Challenges for regional Australia in the context of change. Launceston, TAS: Centre for Research and Learning in Regional Australia, University of Tasmania.

Pattberg, P., Biermann, F., Chan, S., \& Mert, A. (2012). Public-private partnerships for sustainable development: Emergence, influence and legitimacy. Cheltenham: Edward Elgar.

Robertson, I. (2008). VET teachers' knowledge and expertise (vocational education and training) (Report). International Journal of Training Research, 6(1), $1-22$.

Sparkes, A. (1990). Curriculum change and physical education: Towards a micropolitical understanding. Geelong, VIC: Deakin University Press.

Sparkes, A. (1991). Curriculum change: On gaining a sense of perspective. In N. Armstrong \& A. Sparkes (Eds.), Issues in physical education (pp. 1-19). London: Cassell Education. 
United Nations General Assembly. (2015). Seventieth session A/70/L.3 Building a peaceful and better world through sport and the Olympic ideal. Retrieved from http://unipd-centrodirittiumani.it/public/docs/UNGA_A_RES_70_4.pdf

Zeichner, K. (2010). Rethinking the connections between campus courses and field experiences in college and university-based teacher education. Journal of Teacher Education, 61(1-2), 89-99. 